The report refers to the much-publicized subject of "Investigations on Human Subjects", and in this report 41 pages are devoted to an important statement of the Council's views as to the considerations which should govern medical men who may propose for one reason or another to carry out experiments on human volunteers in order to advance beneficent knowledge. This statement will be heartily welcomed by all modical men and research workers. Important also and of great interest to all medical men and biologists is the section of the report entitled "Some Aspects of Medical Research", which will be published separately together with the Council's statement on responsibility in investigations on human subjects, under the title Current Medical Research (H.M.S.O. 4s. 6d.). As most readers will know, this section has been a feature of previous reports and has been published separately under the same title. This year it discusses the theoretical basis of organ transplantation; chromosome damage in man following exposure to ionizing radiations; clinical genetics and its applications (illustrated by 3 plates); recent studies on the control of ovarian function; microbial drug resistance; the chemotherapy of cancer; protein turnover in the central nervous system; and epidemiological research in psychiatry. All these articles have valuable bibliographies.

The rest of the report is devoted to an extensive summary of all the research work being done under the auspices of the Council, with details of the personnel employed in various capacities and indexes of their names and of the subjects they are working on and of the establishments in which they are working.

Taken as a whole, the report provides a valuable epitome of the main trends of the medical and biological research now being done not only in Britain but also in the tropies and elsewhere. The Council's work is unique. It deserves the widest publicity, for a nobler example could scarcely be found of the devoted co-operation of men and women of all grades of skill and experience for the benefit of their fellows all over the world.

\section{G. LAPAGE}

\title{
A HALF-CENTURY OF FRUIT RESEARCH
}

$\mathrm{S}^{\mathrm{T}}$ NCE there have been less than forty half-centuries since the beginning of our present dating era, a jubilee provides a sufficient lapse of time over which to review progress in any field of sustained human effort. That East Malling Research Station came into being before the First World War was a major achievement, for money and effort wore then but sparsely invested in the pursuit of new knowledge. The Station's first contribution to the fruit-growing industry was spectacular-the classification of rootstocks to give, for the first time, reliable, regulated production in orchards - and the name of its early director, R. G. (later Sir Ronald) Hatton, is inseparably linked with this. It was almost inevitable that subsequent contributions had to become more detailed-more intensive investigations of smaller parts of the whole problem of fruit production. Papors delivered during the three-day jubilee celebrations therefore give a unique opportunity for reviewing the work at East Malling as a practical whole*.

A true perspective was introduced at the outset in a paper by W. S. Rogers and D. W. Way, who, speaking of strawberry culture, stated bluntly "the need is for cheaper production and greater economy of labour, and the most likely contribution to this, on the cultural side, is in the use of herbicides". This conclusion followed a gratifyingly long-term reviow of all aspects of culture, for W. S. Rogers has been concerned with the trials for thirty-six years. R. I. C. Holliday spoke of the herbicides, of which simazine has proved the outstanding material so far for soft fruits. The work on rootstocks still continues, and W. S. Rogers discussed the features of Malling-Merton $104,106,111$ and Malling XXV among others. Trees are also being worked 12 in. above the ground to give a 'builtin' insurance against the soil-borne fungus causing collar rot. Sufficient water is a basic need for any crop, and $J$. E. Goode domonstrated average increases per acre of $4 \mathrm{cwt}$. of black currants per in. of water applied as irrigation. D. W. P. Greenham, investigating problems of manuring and soil management, has also linked them with water needs. Dessert apples have not responded greatly to applications of phosphate or potassium, and after being planted for 32 years have only responded to light dressings of nitrogon during the past ten. This work seems to indicate the need for careful timing of the applications of water and nitrogen to give the maximum desired effect.

* The Kent Incorporated Society for Promoting Experiments in Horticulture. Jubilee Annual Report of the East Malling Research Station, Maidstone, Kent, 1st October, 1962, to 30th September, 1963. Pp. xxx+208. (Fifty-first year.) (East Malling, Maidstone: East Malling Research Station,
1964.) 17s. $6 d$.; 2.50 dollars.
The long-term nature of this work also is particularly valuable. Still on the subject of management, J. F. Wilson showed that proper composting of hop bines and trash after picking by stationary machine destroys the Verticillium fungus causing wilt. This is a most welcome adaptation to a modern economic tendency, and provides better facilities for checking the spread of Verticillium than those previously possible.

It takes a great deal of detailed research to simplify and improve measures of direct control of fungal and bacterial diseases, but there are three most welcome instances of this. Botrytis fruit rot of strawberries is a tantalizing disease of greatly varying severity between localities in the same season, and between seasons in the same locality. M. H. Moore has shown that much infection arises from earlier attack of the fungus during flowering, so a spray of thiram or captan then is far more effective than later. Apple scab and apple mildew are now being controlled by sprays designed to reduce infection in the spring, and Gloeosporium diseases in store by reducing infection in the orchard between July and September (J. E. Crosse). Spores of the Verticillium wilt fungus of hops are relatively short-lived in the soil (G. W. F. Sewell and J. F. Wilson). They do not attack grasses, thus suggesting measures of control by grassing down for short periods and linking with the control by composting mention $ə d$ here. Life-cycle investigations of codling moth and tortrix have also led to more effective timing of sprays against these insects, as described by G. H. L. Dicker. There are now highly efficient insecticides, but their very efficiency brought an increase of fruit-tree red spider mite which requires separate control.

Virus diseases limit fruit production greatly, and A. F. Posnette reviewed the methods of virus control-relative isolation of stocks, the planting of healthy material, the control of aphids and other vectors and the thrilling development of heat therapy. The recognition of leafhopper and soil nematode vectors has brought new methods of control, but the older methods of planting only virus-free stocks are still highly effective, for "trees (now ten years old) of our cherry and plum mother tree clones have yielded three times the crop produced by virusinfected trees often used for planting orchards in the past". J. T. Legg showed that degeneration of the hop can bo explained by the joint attack of 'nettlehead' and 'line pattern' viruses, but here again, vigour can be maintained by planting only virus-tested stocks supplied by the Station through the Ministry of Agriculture's A-plus scheme. 
R. V. Harris, in an introductory paper on hop problems, outlined, inter alia, the part that could be played in disease control by the breeding of resistant or tolerant varieties. 'There are always variations within such varioties, but $\mathrm{P}$. W. Talboys concluded that "variation in response to local environmontal factors will always tend to be large in varieties of intermediate resistance, but small in very sensitive or very resistant varieties". He also showed that resistance to Verticillium wilt depends on the more rapid completion of endodermal suberization, and the production of highly tolerant varieties is thus placed on a sure basis. East Malling has produced new varieties of black currant and a whole range of raspberries; R. L. Knight and Elizabeth Keep discussed patterns for remodelling varieties for resistance to aphids and Botrytis fungi, black currant varieties for new strig type and resistance to gall mite, gooseberry for spinelessness and resistance to American gooseberry mildew, and all for high yield and quality. There are also somo interesting interspecific crosses.

One might perhaps predict for the future that, as the groat practical work of the Station is now to reduce costs for the industry, more assessment will become necessary of the relative expenditure required for the various new operations introduced by research. There is nothing mercenary about this, for as the World wants more food, it wants it without the expenditure of undue human energy, and the scientific measure of such energy is ultimately based on its cash value. In reviewing the sustained work of the Station as a whole I have, unfortunately, omitted mention of twenty-five detailed papers, a general review and four bulletins for fruit growers which indeed occupy the bulk of the report. Apologies to the authors of these, but warmest congratulations on the Jubilee, thus fortified by an acute appreciation of the Station's work.

J. GRAINGER

\section{SCIENCE IN THE JUNIOR SCHOOL}

$I^{\mathrm{N}}$ $\mathrm{N}$ the initial competition for the Guinness Awards for Science Teachers in Training, held in 1963, the first prize was gained for their joint work by two students, Sheila Stafford and David Horswill, of the City of Leeds Training College. A slightly edited version of their entry has now been published as a special Supplement to The Science Teacher (7, No. 7; July 1964). It needs to be appreciated that, at the time when they wore producing their essay, the classroom experience of these two students was limited mainly to their periods of school practice and observation of teachers in action, so that they were drawing on their own academic studies, which included among othors the writings of Susan Isaacs, J. Piaget, and Cyril Burt.

Following a trend which is gathering strongth, they have broken away from the tradition that for young children nature study provides tho best introduction to science. Instead, they consider that the aim should be to holp boys and girls to gain confidence in scientific methods of enquiry and experiment, and train them to think methodically and logically, so that, within the scope of their abilities, they may gain an understanding of selected aspects of the world around them, in accordance with the needs of society. There should be no fixed syllabus, although, while allowing for flexibility, the course should not lack cohesion; and the driving-power should come from the children's own interests, the toachor sensing "when to follow, when to discuss, explain, teach or guide". In this way they believe the teacher can provide oppcrtunities for progressive observation and experiment which will lead to deeper understanding and the formulation of simple, genoral laws -as, for example, those relating to elementary magnetism and the reflexion of light.

'The essay includes sections on such topics as the help teachers can give in building up concepts, project work, and the value of class discussion; and it ends with an outline syllabus for children of soven to eleven years old. Although somewhat discursive and repetitive, it is a commendable piece of work, well in line with modern developments in the junior school; and it indicates that the scheme of Guinness Awards for Science Teachers in Training is serving a useful cause. It also highlights the need for more attention to be directed, at full research level, to a still greater cause, that of gaining a better understanding of individual attitudes, interests and abilities, in relation to science, throughout the whole of tho educational period.
R. Whatherall

\section{INDUSTRIAL DESIGN}

$\mathrm{I}^{\mathrm{N}}$ a debate in the House of Lords on June 17 Lord Peddie directed attention to the annual roport of the Council of Industrial Design and referred to the recent Fiolden Report on Engineering Design. The latter had expressed tho view that Britain's share of international trade in engineering goods had been declining because, in spite of many notablo successes, many British products woro boing outclassed in performance, reliability and sales appeal. Lord Peddie reforred to the importance of raising the standards of design. He thought that design in industry was never more important than it is to-day, and he also thought it unfortunate that industrial design was mentally closely identified with art. During the past twenty years the Council of Industrial Design had played a significant part in increasing the awareness that good design was an expression of creative gonius and of the importance of the whole subject. But he thought that it was necessary to increase substantially the work of the Council and to extend its activities into designs not at present covered by the Design Contro, capital goods and engineering industries. $H_{\Theta}$ thought a closer associ- ation would be justified between the Council and the Department of Scientific and Industrial Research. It was oncouraging to soe that the Royal College of Arts was now recognizing the importance of greater attention to the problem of industrial design, and Lord Peddie also referred to tho proposal for a university on design and tochnology in northern Middlesex.

The Minister of State (Board of Trade), Lord Drumalbyn, referred briefly to the development of industrial design to put the question of design into perspective. Ife pointed out that the new profession of industrial designing had formally been recognized loss than thirty years ago (1936) when the Royal Society of Arts founded the distinction of Royal Designer for Industry, of which there were now 48 in addition to 13 honorary foreign holders of the distinction. The Council of Industrial Design and its Scottish Committeo had been formod in 1944 to promoto by all practical means the improvement of design in the products of British industry, and in 1956 the Design Centre had been established at 28 Haymarket, London, S.W.I: the 